\title{
ANALISIS ANALISIS PRODUK KERAJINAN LAMPU HIAS DARI BATOK KELAPA PADA PERAJIN WAK JEK ART (WJA) DI MEDAN DITINJAU DARI BENTUK
}

\author{
Adriman Manalu ${ }^{*}$, Mesra $^{2 *}$ \\ Program Studi Pendidikan Seni Rupa Jurusan Seni Rupa Fakultas Bahasa dan Seni \\ Universitas Negeri Medan \\ Jl. Willem Iskandar Pasar V Medan Estate, Kec, Percut Sei Tuan, Kab. Deli Serdang, Kode Pos 20371 \\ Sumatera Utara. Indonesia \\ Email: manaluadriman92@gmail.com
}

\begin{abstract}
Abstrak
Penelitian ini bertujuan Untuk mengetahui bentuk lampu hias yang sudah memenuhi kriteria sebagai lampu yang fungsional untuk penerangan. Untuk mengetahui bentuk lampu hias yang sudah memenuhi kriteria sebagai elemen interior yang artistik. Dalam penelitian ini peneliti menggunakan Teori Sugiyono (2011:117) mengatakan: populasi adalah wilayah generalisasi yang terdiri atas: obyek/subyek yang mempunyai kualitas dan karakteristik tertentu yang ditetapkan oleh peneliti untuk dipelajari dan kemudian ditarik kesimpulannya. Penelitian ini dilakukan di Jalan Alumunium 1. No 129 A Medan. Hasil penelitian bentuk batok kelapa yang ada pada kerajinan WJ Art ditinjau dari dari bentuk adalah bentuk lampu hias yang terdapat dari keseluruhan adalah lampu hias duduk. Dalam penelitian, peneliti meneliti berdasarkan 4 aspek yaitu aspek kekuatan, aspek ukuran, aspek keindahan , dan aspek kesesuaian. serta dari ke 6 sampel penelitian, peneliti menemukan bahwa dari keseluruhan hasil penelitian nya berkategorikan B ( 80-89) dengan rata-rata dari semua hasil penelitian berjumlah 85.
\end{abstract}

Kata Kunci: analisis batok kelapa, bentuk.

\begin{abstract}
This study aims to determine the shape of decorative lights that have met the criteria as functional lights for lighting. To find out the shape of decorative lights that have met the criteria as artistic interior elements. In this study researchers used the Sugiyono Theory (2011: 117) said: population is a generalization region consisting of: objects / subjects that have certain qualities and characteristics set by researchers to be studied and then conclusions drawn. This research was conducted on Aluminum Road 1. No. 129 A Medan. The results of the study of the shape of coconut shells that exist in the craft of WJ Art in terms of the shape is the shape of the decorative lights contained in the whole are decorative sitting lamps. In research, researchers examined based on 4 aspects, namely aspects of strength, aspects of size, aspects of beauty, and aspects of conformity. and from the 6 study samples, the researchers found that the overall results of the study were categorized as $B(80-89)$ with the average of all research results amounting to 85
\end{abstract}

Keywords: coconut shell analysis, form.

\section{PENDAHULUAN}

Karya seni secara umum dipahami sebagai suatu karya tiga dimensi. Karya seni dikerjakan dengan mempergunakan alat-alat sederhana dan mengandalkan kesabaran serta keterampilan agar karya yang dihasilkan menjadi bernilai tinggi serta dapat dilihat dari segi kualitas dan estetika pada produk kerajinan tersebut.

Kerajinan merupakan produk yang dihasilkan manusia yang dapat dilihat dari berbagai aspeknilaifungsional dan kegunaan. Maka dari itu bahan, bentukdan juga penyesuaian warna harus diteliti dan diperhatikan oleh perajin.

Batok kelapa salah satu bahan yang biasa digunakan oleh perajin karena memiliki sifat keawetan dan ketahanan terhadap air. Kerajinan terbuat dari produk batok kelapa tergolong kategori rendah, sementara saat ini produk-produk kerajinan dengan teknologi sudah bermunculan dengan variasi sehingga menjadi saingan bagi kerajinan batok kelapa tersebut, namun demikian kerajinan batok kelapa sangat berpotensi untuk dikembangkan dengan tambahan gagasan ide seni rupa perajin. 
Perajin WJ Art salah satu yang telah memproduksi kerajinan dari limbah batok kelapa menjadi benda seni yang berkualitas, WJ Art menciptakan lampu hias dari batok kelapa, yang terinspirasi dari sekitar rumahnya yang terdapat banyak limbah batok kelapa.

WJ Art mulai menekuni seni kerajinan mulai pada tahun 2008, di daerah Jalan Alumunium 1, Tanjung Mulia Medan. Hasil karya ciptaannya WJ Art sudah memproduksi bermacam lampu hias dari batok kelapa tersebut. Perajin WJ Art mengkombinasi bahan-bahan lain, seperti kayu, rotan dan lain-lain untuk menghasilkan lampu yang lebih indah dan menarik.

Hasil karya lampu hias ciptaan WJ Art menjadi ciri khas kerajinan lampu hias dari batok kelapa. Apasaja bentuk lampu hias dari bahan batok kelapa yang terdapat di perajin WJ Art, apakah lampu hias duduk, menempel atau tergantung di langit-langit plafon rumah.

Kendala yang dihadapi pada saat pembuatan lampu hias yang dibuat oleh perajin WJ Art, apakah peralatan yang belum sepenuhnya memakai peralatan modern atau ada kendala lain, seperti kombinasi dari bahanbahan tertentu, dalam penciptaan lampu hias dari limbah batok kelapa apasaja fungsi lampu hias yang dibuat oleh perajinWJ Art, apakah hanya sebagai penghias dekorasi rumah, sebagai lampu tidur, atau lampu belajar. Dimana daya tarik lampu hias dari bahan batok kelapa yang dihadirkan oleh perajin WJ Art, apakah bentuknya yang unik, atau bahannya yang terbuat dari limbah batok kelapa.

Proses penerapan desain pada batok kelapa mengalami kesulitan, karena batok kelapa mudah pecah, harus hati-hati dalam membentuk potongan batok, serta kendala yang lain seperti kombinasi bahan cenderung tidak bervariasi, sehingga bentuk yang terdapat kurang indah karena perpaduan yang terdapat tidak banyak memakai bahan lain.

\section{KAJIAN TEORI}

\section{Profil Perajin}

Zainal adalah perajin batok kelapa, yang menghasilkan bentuk lampu hias, WJ Art adalah nama usaha dari zainal dimana Artinya adalah Wak Jek Art, WJ Art sudah berdiri sejak tahun 2016, WJ Art sudah banyak mengikuti pameran bazar di Medan, yaitu UKM Koperasi, Dekranasda Sumut, Bank Sumut, Bazar Ulang Tahun Medan, lokasi pembuatan WJ Art di Jalan Alumunium 1 No.29 A Medan, dalam pembuatan lampu hias dari batok WJ Art melakukannya sendiri, dikarenakan dalam pembuatannya WJ Art lebih suka memakai imajinasinya sendiri.

\section{Pengertian Kerajinan}

Kerajinan merupakan hasil budaya bangsa dengan keanekaragaman bentuk, corak, danfungsi yang semuanya itu menggambarkan citra bi · ‘ ’sa. Kerajinan bias berarti lahir dari sifat $t_{\text {}} \quad 188$ tuk mewujudkan corak dari suatu budaya. Senı kerajınan mempunyai sejarah perkembangan yang cukup panjang di mana dahulu kerajinan digunakan sebagai alat kebutuhan sehari-hari dan dibutuhkan sebagai alat pemuas kebutuhan hidup yang dilakukan melalui keindahan.

\section{Pengertian Estetika}

Istilah estetika diperkenalkan oleh filsuf bernama Baumgarten (1714-1762), seorang filosof Mazhab Leibnitio-Wolfian Jerman dalam karyanya "Meditationes" (1735) ( Andry 2009). Estetika berasal dari kata Yunani "aesthesis" atau pengamatan adalah cabang filsafat yang berbicara tentang keindahan. Objek dari estetika adalah pengalaman akan keindahan, seperti keindahan jasmani dan keindahan rohani, keindahan alam dan keindahan seni, kemudian diselidiki emosi manusia sebagai reaksi terhadap yang indah, agung, tragis, bagus, mengharuhkan dan sebagainya (Surajio,2005:101).

\section{Pengertian Bentuk}

Menurut Kiswanto dalam (Jurnal Kajian Seni 2017:138) Bentuk dan konten (isi) merupakan dua aspek kesatuan yang menjadi esensi (nilai) dasar suatu karya seni. Seni kerajinan bisa diamati menurut fungsinya. Feldman (1967) dalam bukunya yang berjudul Art As Image And Idea, terjemahan Gustami (1991:2) dengan judul Seni Sebagai Wujud Dan Gagasan menjelaskan, bahwa fungsi-fungsi seni yang telah berlangsung sejak zaman dahulu, adalah untuk memuaskan: a. Kebutuhan-kebutuhan sosial untuk keperluan display, perayaan, dan komunikasi; b. Kebutuhan-kebutuhan fisik mengenai barang-barang dan bangunan-bangunan yang bermanfaat.

Saliya, (1999:44) Fungsi dapat dikategorikan sebagai penentu atau panduan menuju bentuk. Fungsi menunjukan kearah mana bentuk harus ditemukan. Fungsi dan bentuk memang diperlukan untuk menjelaskan arsitektur, tapi belum memadai (necessary but not efficient).

Menurut Genchev, Y. \& Marinova, M dalam Journal of Wood Science, Design and Technology (2013.29) Light, form and material expressiveness are used as major compositional components in organizing the 
architectural space in order to achieve an aesthetic impact on people.. Artinya Cahaya, bentuk dan ekspresif material digunakan sebagai komponen komposisi utama dalammengatur ruang arsitektur untuk mencapai dampak estetika pada manusia.

\section{METODE PENELITIAN}

Beberapa cara peneliti memperoleh dan mengumpulkan data. Yaitu dengan menggunakan teknik observasi, wawancara dan dokumentasi. Menurut Arikunto (2010:40) observasi seringkali diartikan sebagai suatu aktivas yang sempit, yakni memperhatikan sesuatu dengan menggunakan mata. Didalam pengertian psikologik, observasi atau yang disebut pula dengan pengamatan, meliputi kegiatan pemuatan perhatian terhadap sesuatu objek dengan menggunakan seluruh alat indra. Menurut Kartono (1980:142) pengertian observasi adalah studi yang disengaja dan sistematis tentang fenomena sosial dan gejala-gejala psikis dengan jalan pengamatan dan pencatatan. Hasil wawancara disimpan dalam bentuk rekaman kemudian akan diputar dan pada waktu verifikasi data untuk memperoleh kecocokan dengan data yang dihimpun melalui observasi dan dokumentasi. Dokumentasi yakni dilihat dari proses pembuatan dan hasil kerajinan lampu hias. Alat dokumentasi menggunakan kamera, yang nantinya akan dipergunakan sebagai bahan pertanggung jawaban laporan penelitian. Analisis data adalah proses mencari dan menyusun secara sistematis data yang diperoleh dari hasil observasi wawancara, catatan lapangan, dan dokumentasi, dengan cara mengorganisasikan data ke dalam katagori, menjabarkan kedalam unit, melakukan sintesa, menyusun ke dalam pola, memilih mana yang paling penting dan yang akan dipelajari, dan membuat kesimpulan sehingga mudah dipahami oleh diri sendiri maupun orang lain.

\section{HASIL DAN PEMBAHASAN}

1.Hasil

Berdasarkan perumusan masalah yang telah ditentukan pada bab 1, yaitu bagaimana bentuk lampu hias yang memenuhi kriteria sebagai lampu yang fungsional untuk penerangan, dan bagaimana bentuk lampu hias yang memenuhi kriteria sebagai elemen interior yang artistik. Data penelitian karya produk lampu hias dari pemanfaatan batok kelapa karya WJ Art. Diperoleh dari beberapa sumber foto, antara lain sumber foto yang diambil berdasarkan metode observasi (peninjauan kelokasi pembuatan lampu hias dari pemanfaatan batok kelapa), dokumentasi (membuktikan kebenaran karya dengan memfotonya).
Gorga Jurnal Seni Rupa

Volume 08 Nomor 01 Januari-Juni 2019

p-ISSN: 2301-5942 | e-ISSN: 2580-2380

Semua metode ini memfokuskan pada karya kerajinan batok kelapa seperti kriteria sebagai lampu yang fungsional untuk penerangan dan sebagai elemen interior yang artistik dihasilkan kerajinan WJ Art. Metode penelitian ini adalah deskriptif kualitatif.

\section{Pembahasan \\ 1).Lampu Hias}

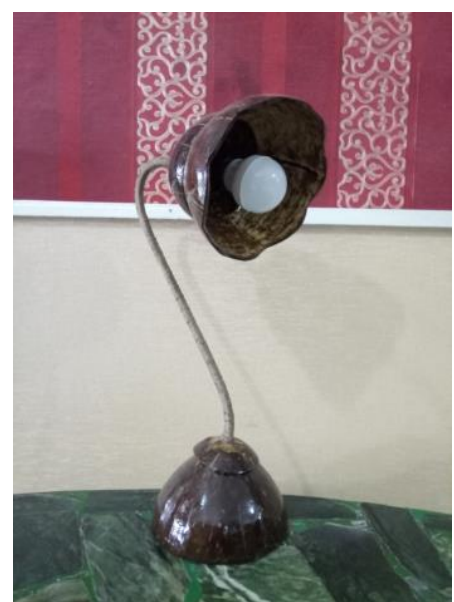

Gambar 1. Lampu Hias 1

(Sumber: Adriman Manalu, 2019)

Pada hasil karya lampu hias pertama menunjukan hasil bentuk pada produk lampu hias dari pemanfaatan batok kelapa karya WJ Art yaitu bentuk yang menyerupai leher angsa yang dimana bentuk ini didasarin oleh ide pengrajin dengan bentuk yang unik. Bentuk yang digunakan yang terdapat pada lampu hias yaitu bentuk yng sederhana tanpa ada banyak aksesoris lainnya, serta pada batang leher lampu dibuat elastis agar dapat diputar-putar.

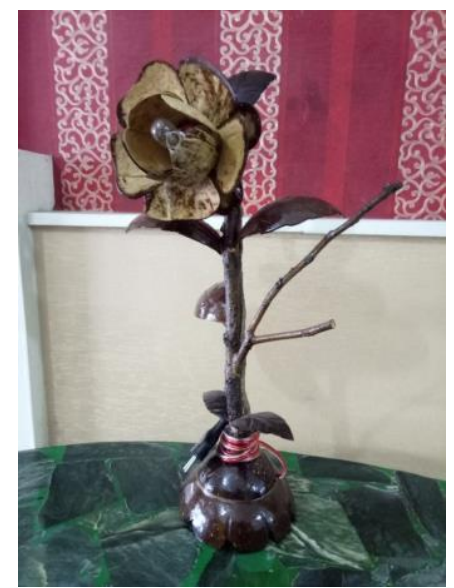

Gambar 2. Lampu Hias 2

(Sumber: Adriman Manalu, 2019)

Pada hasil karya lampu hias kedua menunjukan hasil bentuk produk lampu hias dari pemanfaatan batok kelapa karya WJ Art yaitu bentuk yang menyerupai bunga, bentuk ini didasarin oleh ide pengrajin dimana bentuk yang unik, terinspirasi dari bentuk bunga, dimana pemanfaatan ranting digunakan sebagai bahan 


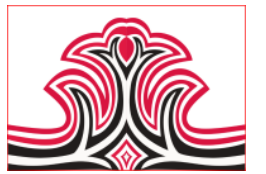

penunjang dalam komposisi keseluruhan lampu, serta ranting yang terdapat pada lampu hias ini sebagai keseluruhan komposisi keindahan.

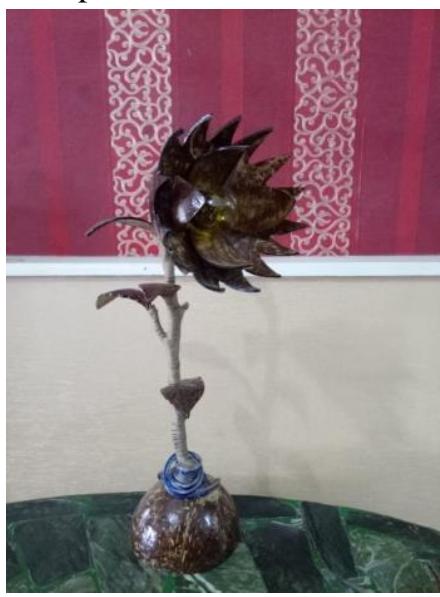

Gambar 3. Lampu Hias 3

(Sumber: Adriman Manalu, 2019)

Pada hasil karya lampu hias ketiga menunjukan hasil bentuk produk lampu hias dari pemanfaatan batok kelapa karya WJ Art yaitu bentuk yang menyerupai bunga matahari, bentuk ini didasarin oleh ide pengrajin dimana bentuk yang unik, terinspirasi dari bunga yang ada disekitar area rumah pengrajin, serta pemanfaatan tali goni pada batang lampu hias ini adalah sebagai keindahan lampu dimana tali goni dililitkan pada batang tiang, serta warna yang terdapat pada lilitan tidak diwarnain melainkan warna asli tali goni tersebut agar selaras dengan warna dari keseluruhan lampu hias.

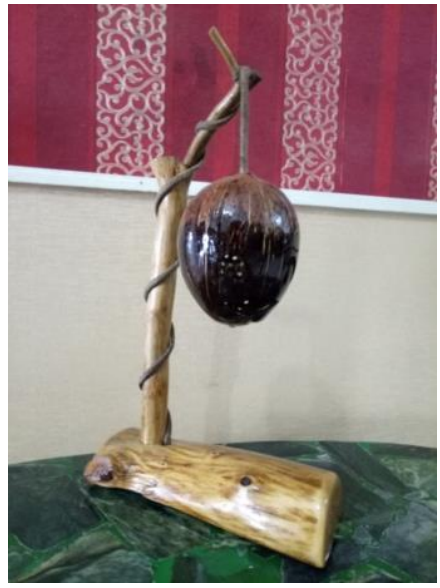

Gambar 4. Lampu Hias 4

(Sumber: Adriman Manalu, 2019)

Pada hasil karya lampu hias keempat menunjukan hasil bentuk produk lampu hias dari pemanfaatan batok kelapa karya WJ Art yaitu bentuk yang menyerupai buah yang tergantung di ranting pohon, dengan bantuan lilitan benang goni dia area batang serta dengan tapak sebongkah kayu. Terlihat pada lampu hias ini pemanfaatan bongkahan kayu dipadukan dengan ranting, dan lilitan benang goni pada kabel lampu hias.
Gorga Jurnal Seni Rupa

Volume 08 Nomor 01 Januari-Juni 2019 p-ISSN: 2301-5942 | e-ISSN: 2580-2380

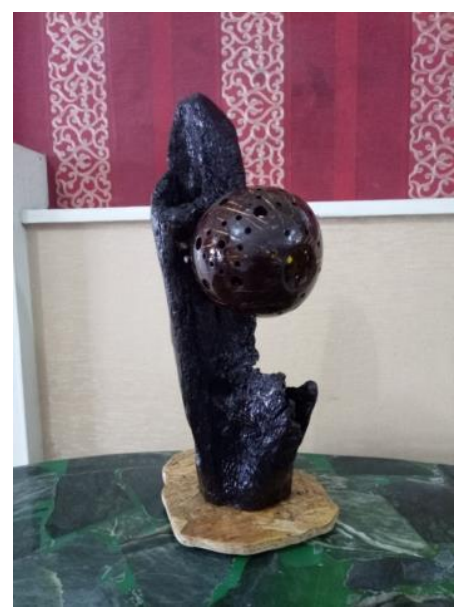

Gambar 5. Lampu Hias 5

(Sumber: Adriman Manalu, 2019)

Pada hasil karya lampu hias kelima menunjukan hasil bentuk produk lampu hias yang menggabungkan pemanfaatan sisa kayu dan pemanfaatan batok kelapa karya WJ Art yaitu bentuk yang mengkombinasikan benda yang menempel pada sebatang kayu, dengan batok kelapa yang utuh dilobang-lobangi, agar dapat memancarkan cahaya lampu dari dalam batok kelapa. Terlihat pada lampu hias ini terdapat bongkahan kayu yang didapat dari laut, dipadukan dengan batok kelapa, dijadikan sebuah lampu hias serta diakhir finishing bongkahan kayu di vernis dengan menggunakan warna kopi brown agar terlihat hitam, walaupun jika di lihat secara langsung warna akan terlihat sedikit berbeda yaitu warna coklat tua.

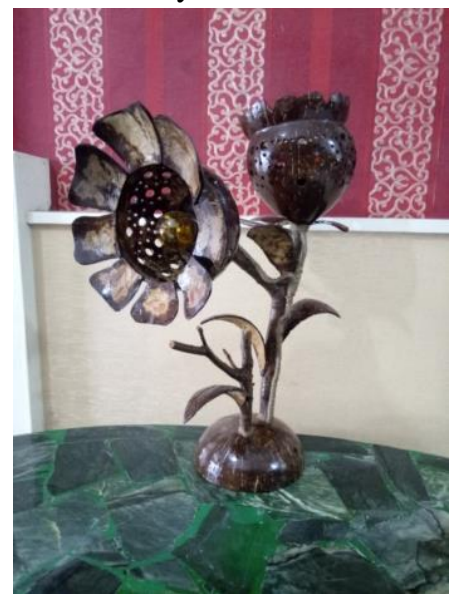

Gambar 6. Lampu Hias 6

(Sumber: Adriman Manalu, 2019)

Pada hasil karya lampu hias keenam menunjukan hasil bentuk produk lampu hias yang menyerupai bunga, dimana daun yang terdapat pada lampu juga terbuat dari batok kelapa. yang dimana penggabungkan pemanfaatan pada batok kelapa bisa dilihat dari bunganya yang ada dua, satu mekar dan satunya lagi berbentuk kuncup, serta terdapat juga pemanfaatan ranting pada tiang lampu hias ini, pada bunga yang terbuat dari batok kelapa ini dilobangi agar dapat memancarkan sinar. 


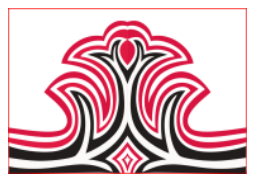

\section{KESIMPULAN DAN SARAN}

1.Kesimpulan

Berdasarkan rumusan, tujuan, hasil, dan pembahasan penelitian analisis produk kerajinan lampu hias batok kelapa pada perajin WJ Art diperoleh kesimpulan sebagai berikut. Bentuk lampu hias yang memenuhi kriteria sebagai lampu yang fungsional untuk penerangan memiliki proporsi mengacu pada ukuran relatif dan skala berbagai elemen dalam desain, perbandingan ukuran dari bagian-bagian bentuk total dengan ukuran keseluruhannya, konsistensi dari suatu konsep menyebabkan aneka elemen di dalam karya sebagai bagian yang disatukan bentuk, dan keseimbangan pada lampu hias.

Bentuk lampu hias yang memenuhi kriteria sebagai elemen interior yang artistik bentuk yang mengikuti fungsional yaitu kebutuhan-kebutuhan sosial untuk keperluan display, perayaan, dan komunikasi, kebutuhan-kebutuhan fisik mengenai barang-barang yang bermanfaat. Bentuk sebagai dekorasi dalam konteks artistik suatu benda yang berfungsi sebagai elemen suatu interior ruangan. Seperti lampu hias pada suatu ruangan menjadi harmonisasian dalam menghadirkan nilai keindahan, kehadiran bentuk dalam ruangan menjadi tata letak yang baik, dalam merancang sebuah tempat dibutuhkan kerjasama, kerjasama yang dimaksud adalah susunan dekorasi, antar elemen.

\section{Saran}

Berdasarkan hasil penelitian dan kesimpulan, maka peneliti menyampaikan beberapa saran sebagai berikut:

1. Produk kerajinan lampu hias yang dihasilkan oleh WJ Art agar lebih dikembangkan untuk membuat lampu hias gantung, dan lampu hias dinding.

2. Produk kerajinan lampu hias yang dihasilkan oleh WJ Art agar lebih divariasikan warna lampunya untuk membuat daya tarik yang lebih dari konsumen.

3. Produk kerajinan lampu hias yang dihasilkan oleh WJ Art agar membuat kemasan khusus agar memudahkan konsumen membawa produk.

4. Produk kerajinan lampu hias yang dihasilkan oleh WJ Art agar lebih dikembangkan menjadi lampu hias batok kelapa yang bisa bongkar pasang.

5. Produk kerajinan lampu hias yang dihasilkan oleh WJ Art agar lebih dikembangkan dalam variasi bentuk, dan lebih bervariasi dengan kombinasi bahan yang lain.
Gorga Jurnal Seni Rupa

Volume 08 Nomor 01 Januari-Juni 2019

p-ISSN: 2301-5942 | e-ISSN: 2580-2380

\section{DAFTAR RUJUKAN}

Arikunto, Suharsimi. (2010). Prosedur Penilitian (Suatu Pendekatan Praktek). Jakarta: Rineka Cipta.

Genchev, Y. \& Marinova, M. (2013). Trends in Modern Home Interior and Furniture. Journal of Wood Science, Design and Technology, 2 (1), 28-33.

Kartono, Kartini. (1980). Pengantar Metodologi Riserch Sosial. Bandung:

Sugiyono. (2011). Metode Penelitian Pendidikan (Pendeketan, Kuantitatif, Kualitatif, dan $R \& D$ ). Bandung: Alfabeta. 